\title{
Wykorzystanie modelowania przestrzennego do wyznaczania stref pod odwierty eksploatacyjne dla PMG działających w obrębie wyeksploatowanych ztóż konwencjonalnych
}

\begin{abstract}
W południowo-wschodniej Polsce wyeksploatowane złoża konwencjonalne, charakteryzujące się korzystnymi parametrami petrofizycznymi, przy odpowiednich warunkach ekonomiczno-technologicznych wykorzystywane są do podziemnego magazynowania gazu ziemnego, czego przykładem są PMG Husów, PMG Strachocina, PMG Swarzów i PMG Brzeźnica. Wykorzystanie oprogramowania komputerowego do modelowania przestrzennego parametrów złożowych w obrębie starych złóż powiązane jest ze znacznym stopniem niepewności wynikającym z dużego zróżnicowania czasowego pozyskanych danych, a także czynników wpływających na ich reprezentatywność. W artykule przedstawiono sposób wykorzystania modelowania dostosowanego do starych złóż piaskowcowych, zakładającego selekcję i przetworzenie zreinterpretowanych profilowań promieniotwórczości naturalnej gamma do wyznaczenia zailenia z użyciem modelu liniowego w celu utworzenia klasyfikacji pseudofacjalnej. Przestrzenna wizualizacja jej elementów, obok interpretacji geologiczno-złożowej, może być wykorzystana do dalszych analiz obejmujących podejmowanie decyzji w aspekcie typowania stref predysponowanych do posadowienia nowych odwiertów związanych ze zwiększaniem pojemności czynnej PMG. Do modelowania użyto oprogramowania Baker Hughes JewelSuite ${ }^{\mathrm{TM}}$ Subsurface Modeling.
\end{abstract}

Słowa kluczowe: modelowanie 3D, Karpaty, zapadlisko przedkarpackie, podziemne magazynowanie gazu.

\section{Determination of perspective zones for wells through the application of spatial modeling within UGS operating in exploited conventional reservoirs}

Exploited conventional reservoirs located in the south-eastern part of Poland, characterized by favorable petrophysical parameters, are being used for underground gas storage under appropriate technological and economic conditions, as exemplified by UGS Husow, Strachocina, Swarzow or Brzeznica. The use of subsurface modeling software for visualizing spatial reservoir parameters' distribution within old gas fields, is associated with a significant degree of uncertainty resulting from a wide variation in time of data acquisition and factors affecting its representativeness. The article presents the concept of using modeling adapted for old, conventional gas reservoirs, assuming the selection and processing of reinterpreted gamma ray logs to create pseudo-facies classification. Visualization of its elements, along with geological and reservoir interpretation, can be used for further analysis, including decision making in the aspect of picking out predisposed zones for new wells associated with increasing UGS total storage capacity. Modeling was conducted with the use of the Baker Hughes JewelSuite ${ }^{\mathrm{TM}}$ Subsurface Modeling software.

Keywords: subsurface modeling, Carpathians, Carpathian Foredeep, underground gas storage.

\section{Wprowadzenie}

Poprawne odwzorowanie budowy geologicznej obszaru złożowego, zarówno na etapie poszukiwawczo-rozpoznawczym, jak i eksploatacyjnym, przynosi szereg korzyści, w tym znacząco zmniejsza ryzyko niepowodzenia podejmowanych działań. Południowo-wschodnia część Polski stanowi najstarszą strefę związaną z wydobyciem węglowodorów w obrębie 
państwa, w związku z czym duża ilość dostępnych danych wykorzystywanych podczas modelowania przestrzennego charakteryzuje się dużą rozpiętością czasową ich pozyskania. Podczas opracowywania danych geofizyczno-geologicznych na tego typu obszarach złożowych, fundamentalne znaczenie ma ocena stopnia reprezentatywności danych oraz ich odpowiednie przetworzenie, ponieważ to od nich zależy późniejsza poprawność modelu. Podczas modelowania każdego parametru popełniany jest błąd, którego wielkość jest uzależniona od czynników wpływających na sam pomiar, a także od metodyki budowania oraz populacji modelu z poszczególny- mi atrybutami złożowymi. Ograniczenie jego wielkości może pozwolić na zwiększenie reprezentatywności odwzorowanej budowy geologicznej struktury złożowej.

W ramach przeprowadzonego modelowania wykonano symulacje wizualizujące przestrzenne zróżnicowanie elementów klasyfikacji pseudofacjalnej, występujących w obrębie struktury złożowej. W ostatnim etapie przeanalizowano zasadność uzyskanych wyników zarówno pod kątem ich poprawności, jak i podejścia metodycznego w aspekcie zastosowania dla złóż konwencjonalnych charakteryzujących się długą historią eksploatacji.

\section{Sytuacja geologiczna}

Południowo-wschodnia część Polski związana jest z małopolską prowincją naftową, w obrębie której najbardziej produktywne strefy pod względem wydobycia węglowodorów na przestrzeni lat dotyczą Karpat i zapadliska przedkarpackiego (rysunek 1).

Karpaty dzielą się na wewnętrzne, górnokredowe pasmo fałdowo-płaszczowinowe oraz zewnętrzne wieku oligocen-środkowy miocen, które są rozdzielone pienińskim pasem skałkowym. Karpaty zewnętrzne (fliszowe) reprezentują utwory wieku górna jura - dolny miocen [12]. W obrębie Karpat odkryto kilkadziesiąt, głównie małych złóż ropy i kilkanaście złóż gazu, z których większość została wyeksploatowana [5]. Znacznie większa ilość dużych złóż powstała w obszarze zapadliska przedkarpackiego. Ten przedgórski, sedymentacyjny basen molasowy powstał na przedpolu Karpat nasuwających się w kierunku północnym, który wypełnia środkowomioceńska sukcesja osadowa wieku baden-sarmat [4, 8]. Biorąc pod uwagę złoża konwencjonalne, największa ich ilość została odkryta w obrębie stref występowania i oddziaływania podmorskich stożków napływowych [7]. W ich obrębie dochodziło do depozycji piaskowców o zmiennej miąższości, zależnej przede wszystkim od wykształcenia tektonicznego podłoża

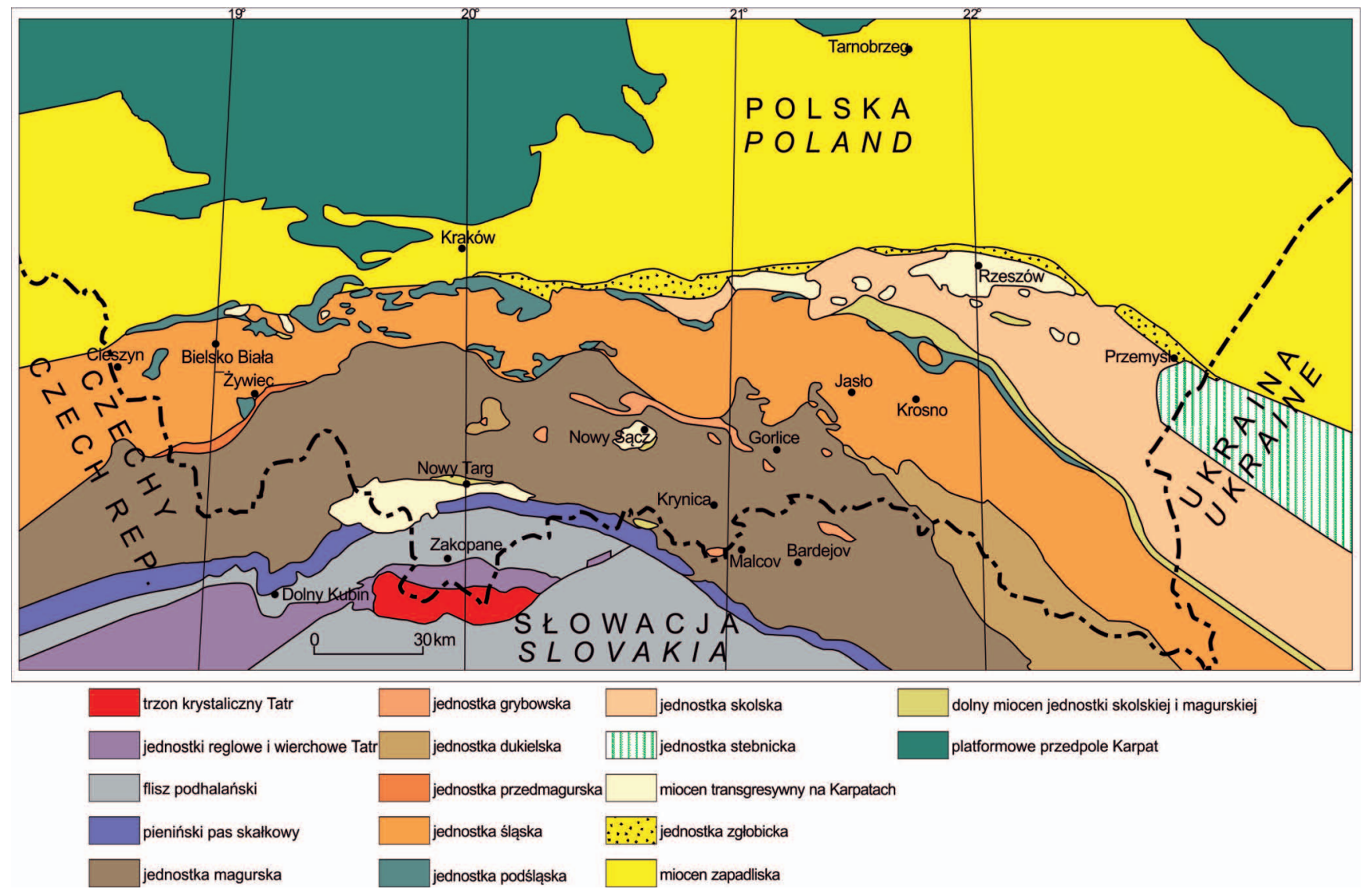

Rys. 1. Szkic tektoniczny polskiej części Karpat i zapadliska przedkarpackiego [9, zmodyfikowano] 
basenu oraz umiejscowienia złoża w stosunku do nasunięcia karpacko-stebnickiego. Niektóre ze złóż charakteryzujące się dobrymi parametrami petrofizycznymi skał zbiorniko- wych wykorzystuje się w charakterze magazynów gazu ziemnego, np.: PMG Husów, PMG Swarzów, PMG Brzeźnica czy PMG Strachocina.

\section{Charakterystyka petrofizyczna skały zbiornikowej}

W obszarze występowania struktury złożowej utwory zbiornikowe dla gazu ziemnego stanowią piaskowce o genezie związanej z działalnością spływów grawitacyjnych. Przeprowadzono na nich szereg badań petrofizycznych, które pozwoliły określić ich charakter w aspekcie złożowym. Piaskowce cechują się znacznym zróżnicowaniem uziarnienia, jednak przeważającą frakcją jest frakcja średnioziarnista, rzadziej drobnoziarnista z domieszkami ziaren frakcji gruboziarnistej oraz żwirowej [3]. Głównie występują one w postaci dobrze wysortowanych piaskowców średnioziarnistych przewarstwionych piaskowcami drobno oraz gruboziarnistymi, a także zle- pieńcami. Spoiwo ma różnorodny charakter i najczęściej występuje w niewielkiej ilości wynoszącej około 4\%6\% objętości, w postaci ilastej, a także ilasto-łyszczykowej, o typie porowo-kontaktowym. Znacznie rzadziej obserwowano próbki piaskowców ze spoiwem węglanowym. Piaskowce były również przebadane w warunkach laboratoryjnych pod kątem ich porowatości i przepuszczalności. Badania wykazały, że stanowią one bardzo dobrą skałę zbiornikową dla gazu ziemnego. Ponadto ich skład mineralogiczny nie wpływa w znacznym stopniu na rozpoznawalność na podstawie profilowania promieniotwórczości naturalnej gamma.

\section{Metodyka}

W celu przeprowadzenia modelowania wykorzystano wszelkie dostępne dane, które mogły mieć wpływ na jakość i reprezentatywność powstałej struktury. Zaliczono do nich przede wszystkim dane otworowe, dane geofizyki otworowej, powierzchnie strukturalne stropów i spągów horyzontów, a także powierzchnie strukturalne uskoków. W obrębie danych otworowych zawarto również głębokości występowania poszczególnych wydzieleń litostratygraficznych oraz dane geofizyki otworowej, które wspólnie stanowiły podstawę interpretacji wykształcenia litostratygraficznego i tektonicznego [6].

Na modelowanym obszarze przeanalizowano dane z ponad 50 odwiertów. Biorąc pod uwagę dostępne krzywe geofizyczne, wykorzystano ponad 30 reinterpretowanych, skorelowanych z rdzeniami wiertniczymi, pomiarów profilowań promieniotwórczości naturalnej gamma, które w przypadku analizowanego typu złóż dobrze sprawdzają się w interpretacji osadów o charakterze piaskowcowo-mułowcowym.

Po przeanalizowaniu rozproszenia zarejestrowanych wartości, sprowadzeniu do tego samego zakresu wartości API oraz obliczeniu zailenia [1], określono przedziały definiujące pseudofacje w postaci piaskowców, heterolitów mułowcowo-piaskowcowych oraz mułowców i łupków ilastych, charakteryzujące się zakresami wartości zailenia wynoszącymi odpowiednio $0,0 \div 0,4 ; 0,4 \div 0,6$ i $0,6 \div 1,0[-]$. Krzywe zailenia obliczono na podstawie wzoru:

$$
V_{s h}=\frac{G R_{\log }-G R_{\min }}{G R_{\max }-G R_{\min }}
$$

$V_{s h}$ - wartość zailenia w danym interwale głębokościowym [-],
$G R_{\log }$ - zarejestrowana wartość profilowania gamma w danym interwale głębokościowym [API],

$G R_{\max }$ - maksymalna zarejestrowana wartość profilowania gamma [API],

$G R_{\text {min }}$ - minimalna zarejestrowana wartość profilowania gamma $[\mathrm{API}]$.

W obrębie budowanego modelu zdefiniowano sześć wydzieleń litostratygraficznych, jako horyzonty A, B, C, D, E oraz F, wyróżniające się charakterem osadów wchodzących w skład struktury złożowej, jak również różniące się stopniem rozpoznania pod względem wiertniczym. W tablicy 1 przedstawiono nazwy wydzieleń litostratygraficznych, liczbę markerów opisujących głębokości występowania stropów danych horyzontów w otworach oraz liczbę dostępnych profilowań promieniotwórczości naturalnej gamma. Najwięcej otworów udostępniło horyzonty A, B oraz C. W przypadku

Tablica 1. Liczba markerów odpowiadających głębokościom występowania stropów horyzontów oraz liczba profilowań promieniotwórczości naturalnej gamma dostępnych w poszczególnych horyzontach

\begin{tabular}{|c|c|c|}
\hline $\begin{array}{c}\text { Nazwa wydzielenia } \\
\text { litostratygraficznego }\end{array}$ & Liczba markerów & $\begin{array}{c}\text { Liczba krzywych } \\
\text { gamma }\end{array}$ \\
\hline Horyzont A & 52 & 30 \\
\hline Horyzont B & 55 & 30 \\
\hline Horyzont C & 39 & 25 \\
\hline Horyzont D & 34 & 19 \\
\hline Horyzont E & 25 & 8 \\
\hline Horyzont F & 18 & 4 \\
\hline
\end{tabular}


horyzontów D oraz E ilość wykonanych odwiertów jest mniejsza, natomiast najsłabiej rozpoznany jest horyzont F. Liczba i miejsce występowania krzywych geofizycznych determinuje reprezentatywność otrzymanych w wyniku modelowania przestrzennych rozkładów parametrycznych.

Mając na uwadze, dla jakich osadów, w jakim środowisku depozycji i w jakich warunkach tektonicznych tworzono model, wygenerowano osnowę strukturalną o rozdzielczości $50 \times 50 \mathrm{~m}$ w płaszczyźnie XY, stanowiącą fundament dla powstającego w późniejszym etapie modelu. Zbudowana osnowa strukturalna determinuje relacje przestrzenne pomiędzy poszczególnymi warstwami wydzieleń litostratygraficznych. Warstwowanie w obrębie horyzontów określono w taki sposób, aby rozdzielczość modelu odpowiadała średniej rozdzielczości pomiarów geofizyki otworowej.

Końcowym etapem było wy-

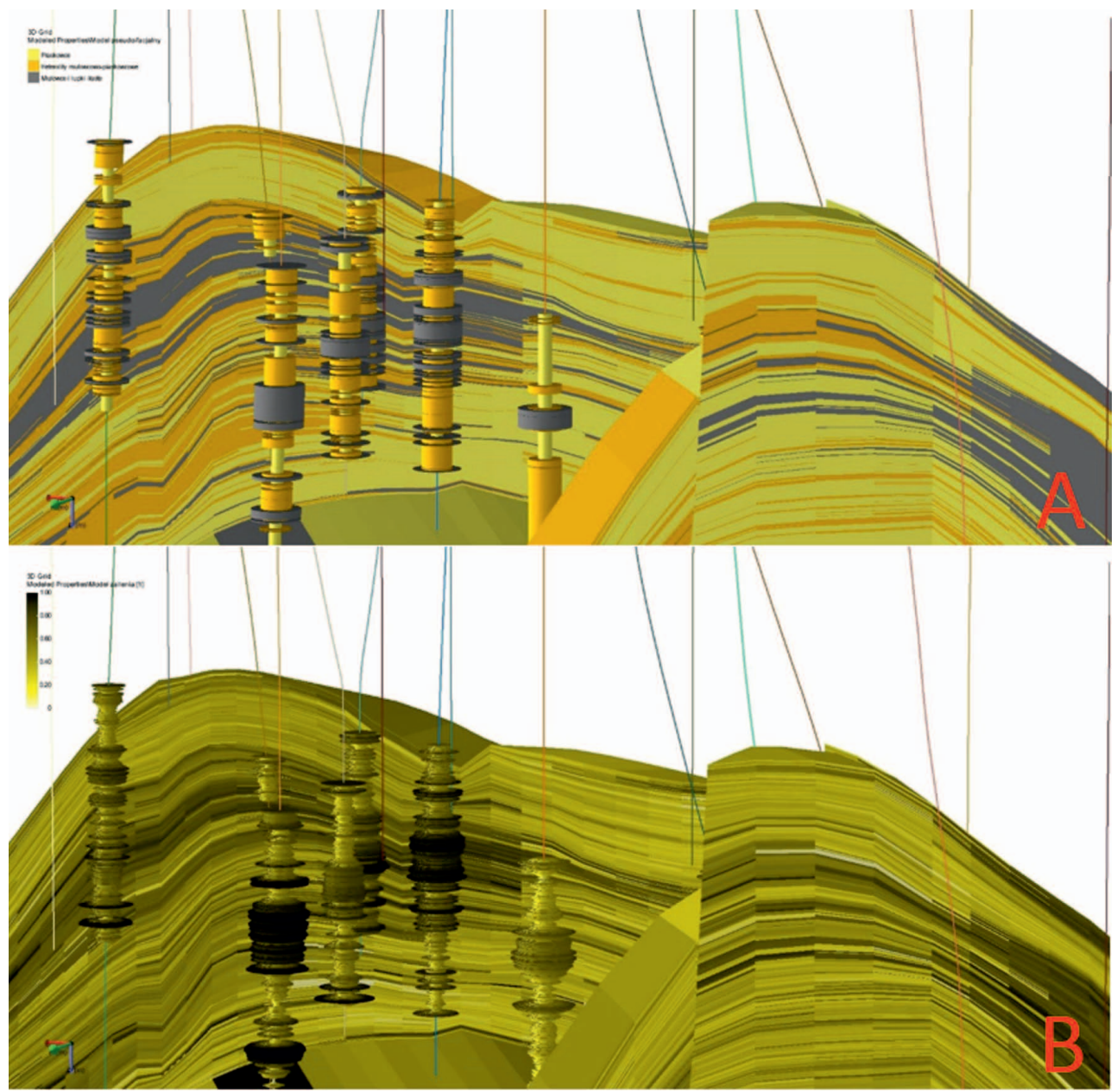

Rys. 2. Przekroje w obrębie modeli wynikowych obrazujących zmienność przestrzenną pseudofacji (A) i zailenia (B) generowanie siatki 3D, w obrębie której przeprowadzono symulacje deterministyczne i stochastyczne z wykorzystaniem

co-krigingu w ramach modelowania pseudofacjalnego i parametrycznego [2] (rysunek 2).

\section{Analiza i ocena wyników modelowania przestrzennego}

W wyniku przeprowadzonego modelowania przestrzennego rozkładu parametrów uzyskano model pseudofacjalny oraz model zailenia. Na wykresie zestawiono wyniki obserwowane w obrębie obydwu z nich - średnie zailenie i objętościowy udział poszczególnych pseudofacji w odniesieniu do każdego wydzielenia litostratygraficznego oraz całego modelu złoża gazu (rysunek 3).

Biorąc pod uwagę całkowitą objętość modelu złoża gazu, największą jego część zajmują piaskowce, wypełniając 48\% przestrzeni. W przypadku osadów odpowiadających heterolitom mułowcowo-piaskowcowym wypełniona objętość wynosi 29\%, natomiast mułowce i łupki ilaste zapełniają pozostałe 23\% modelu. Analizując udział pseudofacji w poszczególnych wydzieleniach litostratygraficznych, obserwuje się kilka prawidłowości. Piaskowce w największej ilości występują w obrębie horyzontu B, gdzie osady te wypełniają 75\% objętości tego wydzielenia, natomiast $\mathrm{w}$ horyzoncie $\mathrm{C}$ znajduje się ich najmniejsza ilość wynosząca 12\%. Najwięcej heterolitów mułowcowo-piaskowcowych obserwuje się w obszarze występowania horyzontu A, gdzie zajmują one 39\%, przy czym ich najmniejszy udział widoczny jest w obrębie horyzontu $\mathrm{F}$, który jest równy $17 \%$. W przypadku mułowców i łupków ilastych wydzieleniem, w którym występuje ich najwięcej, jest horyzont $\mathrm{C}$ - w jego obszarze wypełniają one $51 \%$ objętości. Najmniej osadów reprezentowanych przez tę pseudofację jest obecnych w obrębie horyzontu B. Stosunek rozkładu przestrzennego zailenia do pseudofacji jest zgodny z założeniami określonymi w metodyce. Średnie zailenie dla całego modelu wynosi $45 \%$, natomiast najwyższe i najniższe wskazania tego parametru obserwuje się w horyzoncie $\mathrm{C}$ oraz horyzoncie B i F, które wynoszą odpowiednio 62\% i 33\%. Podczas analizowania uzyskanych wyników istotne jest to, że horyzont $\mathrm{F}$ nie jest tak dobrze rozpoznany jak pozostałe wydzielenia litostratygraficzne (tablica 1). Na tej podstawie można twierdzić, że rozkład przestrzenny parametrów dla horyzontu F jest 
w dużym stopniu zgeneralizowany i zdecydowanie mniej wiarygodny w stosunku do pozostałych, zlokalizowanych w mniejszych interwałach głębokościowych.

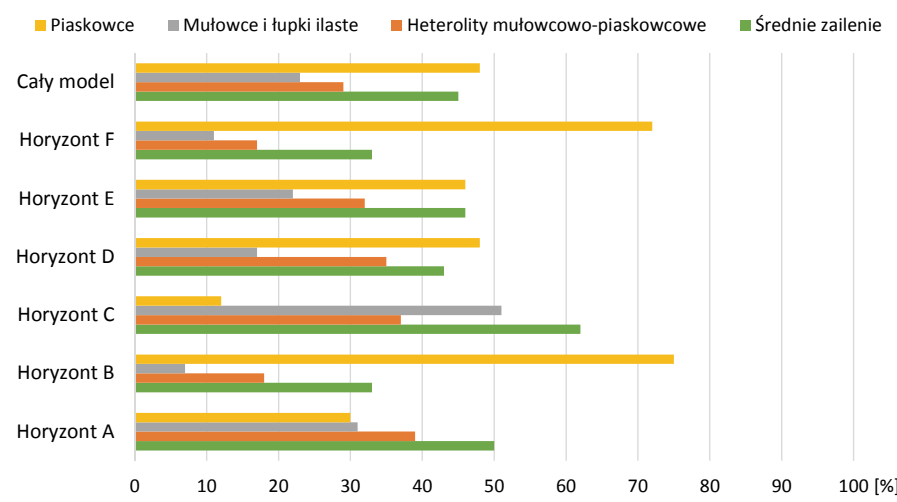

Rys. 3. Zestawienie udziałów objętościowych elementów klasyfikacji pseudofacjalnej oraz zailenia dla poszczególnych horyzontów występujących w obrębie modelu złoża gazu

Jeden z elementów klasyfikacji pseudofacjalnej w postaci heterolitów mułowcowo-piaskowcowych, który został zdefiniowany za pomocą wartości zailenia z przedziału $0,4 \div 0,6$, stanowi istotną strefę przejściową $\mathrm{W}$ analizie przestrzennej. W obrębie całego modelu heterolity mułowcowo-piaskowcowe stanowią 29\% całkowitej objętości, natomiast największą ilość tej pseudofacji obserwuje się w horyzontach A oraz C. Problematykę tego elementu klasyfikacyjnego zobrazowano w zestawieniu jego udziałów objętościowych dla horyzontów C i D (rysunek 4).

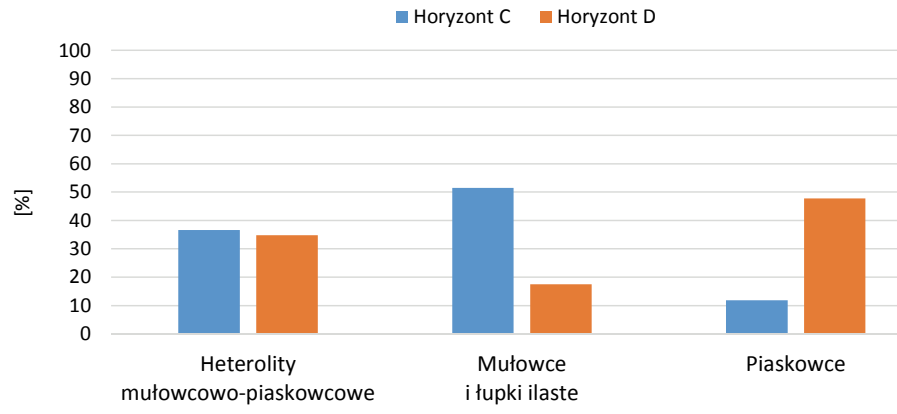

Rys. 4. Zestawienie udziału objętościowego pseudofacji w obrębie modelu złoża gazu dla horyzontów C i D

Jak widać na wykresie, udział objętościowy heterolitów mułowcowo-piaskowcowych w obszarze występowania obu tych wydzieleń litostratygraficznych jest zbliżony i oscyluje w granicach $35 \div 37 \%$. Biorąc jednak pod uwagę pozostałe pseudofacje w postaci piaskowców oraz mułowców i łupków ilastych, obserwuje się, że ich zróżnicowanie jest zdecydowanie większe. Na tej podstawie można stwierdzić, że budowa modelu pseudofacjalnego wyłącznie na bazie zailenia obliczonego metodą liniową, na podstawie pomiarów profilowań promieniotwórczości naturalnej gamma, w odniesieniu do poprawności rozkładu poszczególnych klas, jest obarczona pewnym stopniem niepewności.

Na uzyskane wyniki modelowania wpływa szereg czynników determinujących ich reprezentatywność. Podczas modelowania przestrzennego wykonanego w obrębie złoża gazu o kilkudziesięcioletniej historii eksploatacji wykorzystano dane punktowe, które zawierają informacje obserwowane w konkretnym miejscu w przestrzeni i odwzorowują zmienność jedynie w kierunku pionowym. Dodatkowo są one skalowane do rozdzielczości siatki o wymiarach $50 \times 50 \mathrm{~m}$ w płaszczyźnie XY, co w przypadku stref aktywnych tektonicznie jest dużą generalizacją [10]. Ponadto używane podczas symulacji algorytmy deterministyczne i stochastyczne, głównie kriging, SIS (ang. Sequential Indicator Simulation) czy SGS (ang. Sequential Gaussian Simulation), pozwalają na uzyskanie odwzorowania facjalnego analizowanego obszaru, ściśle uzależnionego pod względem reprezentatywności zarówno od ilości, rozmieszczenia i jakości danych wejściowych, jak i zastosowanej metodyki [11].

$\mathrm{Z}$ tego względu istotne jest zdefiniowanie celowości budowy modelu pseudofacjalnego oraz odpowiednie dostosowanie przedziałów zailenia determinujących przynależność komórek siatki 3D do poszczególnych pseudofacji. W celu zwiększenia precyzji klasyfikacji pseudofacjalnej lub próby utworzenia klasyfikacji facjalnej, uzasadnione byłoby uwzględnienie dodatkowych parametrów złożowych, których przedziały wartości definiowałyby charakter osadów występujących w modelu. W przypadku omawianego typu i charakteru złóż, wyróżniającego się kilkudziesięcioletnim okresem eksploatacji, prawdopodobieństwo wzrostu popełnianego błędu podczas interpretacji przestrzennej może wzrastać wraz z ilością dostępnych danych, a szczególnie tych znacznie różniących się czasem pozyskania, które są inter- i ekstrapolowane w modelowanym obszarze.

W przypadku omawianego typu złóż, fundamentalne znaczenie ma analiza geologiczno-złożowa uwzględniająca szereg czynników wpływających na uzyskane wyniki modelowania przestrzennego, takich jak interpretacja sedymentologiczna i tektoniczna rejonu występowania złoża, czy analiza złożowa uwzględniająca między innymi zmienność ciśnień obserwowanych w otworach wiertniczych. Równie istotny jest wybór danych, które zostaną wykorzystane do modelowania, dobór i odpowiednie zastosowanie algorytmów obliczeniowych, a także określenie parametrów wariogramów definiujących stopień zróżnicowania danego parametru w obrębie struktury. Wykorzystanie klasyfikacji pseudofacjalnej popartej wcześniejszym tego typu rozpoznaniem może stanowić znacznie lepsze źródło informacji przestrzennej, niż przeprowadzenie modelowania na wszelkich dostępnych danych wejściowych, których ilość nie musi świadczyć o reprezentatywności uzyskanych wyników. 


\section{Podsumowanie}

W wyniku przeprowadzonych symulacji uzyskano rozkłady parametrów definiujących przestrzenne zróżnicowanie złoża gazu o długotrwałej historii eksploatacji, w których skład weszły te bazujące zarówno na danych dyskretnych w postaci pseudofacji, jak i ciągłych odpowiadających zaileniu. Zostały one wygenerowane na bazie danych otworowych, pośród których główne źródło informacji przestrzennej stanowiły wyselekcjonowane pod względem reprezentatywności profilowania promieniotwórczości naturalnej gamma oraz interpretacja litostratygraficzna. Wykonana na podstawie zailenia klasyfikacja pseudofacjalna, obok analiz geologiczno-złożowych, może zostać wykorzystana jako pośredni wyznacznik stref predysponowanych pod typowanie miejsc posadowienia odwiertów, mających na celu zwiększenie pojemności czynnej podziemnych magazynów gazu. Na podstawie uzyskanych wyników otrzymano również udziały objętościowe poszczególnych wydzieleń litostratygraficznych w obrębie modelu.

Opisane podejście znajduje uzasadnienie dla złóż charak- teryzujących się znacznym czasem eksploatacji, w przypadku których dostępne dane często cechują się kilkudziesięcioletnim zróżnicowaniem czasu ich pozyskania, co w efekcie wpływa na stopień ich reprezentatywności. Model pseudofacjalny, dla złóż konwencjonalnych powstałych w piaskowcach związanych z Karpatami i zapadliskiem przedkarpackim, w połączeniu $\mathrm{z}$ analizą sedymentologiczną, tektoniczną i złożową, może pozwolić na dostarczenie wartościowych informacji i jednocześnie nie narzucać wniosków płynących z rozkładów przestrzennych, obserwowanych dla parametrów zbiornikowych i filtracyjnych. Należy jednak pamiętać o czynnikach ograniczających jego stosowanie związanych przede wszystkim z typem osadów zbiornikowych, a także jakością pomiarów geofizycznych, rozdzielczością modelu, parametryzacją wariogramów i doborem algorytmów obliczeniowych. W przypadku starych złóż gazu, dobór i odpowiednie wykorzystanie dostępnych danych, w połączeniu z analizą geologiczno-złożową, może być kluczowe w aspekcie minimalizacji ryzyka podejmowanych decyzji.

Prosimy cytować jako: Nafta-Gaz 2018, nr 6, s. 465-470, DOI: 10.18668/NG.2018.06.07

Artykuł nadesłano do Redakcji 4.12.2017 r. Zatwierdzono do druku 26.03.2018 r.

Artykuł powstał na podstawie pracy statutowej pt.: Aktualizacja modelu geologicznego PMG Strachocina-zrealizowanej w INiG - PIB na zlecenie MNiSW; nr zlecenia: 215/0051/17/01, nr archiwalny: DK-4100-38/2017.

\section{Literatura}

[1] Asquith G., Krygowski D.: Gamma Ray. [W:] Asquith G., Krygowski D.: Basic Well Log Analysis $2^{\text {nd }}$ Edition. AAPG Methods in Exploration, nr 16, s. 31-35.

[2] Baker Hughes JewelSuite 6.2 Subsurface Modeling. User Manual. Baker Hughes, 2017

[3] Bromowicz J., Górniak K., Przystaś G., Rembiś M.: Wyniki badań petrograficznych typowych litofacji zbiornikowych fliszu karpackiego. [W:] Kuśnierek J. et al. (red.): Charakterystyka parametrów petrofizycznych fliszowych serii ropogazonośnych Karpat polskich. Polish Journal of Mineral Resources 2001, vol. 4, s. 31-76.

[4] Dziadzio P., Maksym A., Olszewska B.: Sedymentacja utworów miocenu we wschodniej części zapadliska przedkarpackiego. Przegląd Geologiczny 2006, vol. 54, nr 5, s. 413-419.

[5] Karnkowski P.H.: Baseny sedymentacyjne, a prowincje naftowe Polski-zarys problematyki. Przegląd Geologiczny 1997 , vol. 45, nr 10, s. 992-994.

[6] Miziołek M.: Nowe oprogramowanie geologiczne do budowy przestrzennych modeli złóż. Nafta-Gaz 2014, nr 6, s. 343-350.
[7] Miziołek M., Filar B., Cierzniak M.: Pułapki złożowe zapadliska przedkarpackiego w czołowej strefie nasunięcia Karpat. Nafta-Gaz 2017, nr 8, s. 551-556, DOI: 10.18668/NG.2017.08.02.

[8] Myśliwiec M.: Mioceńskie skaty zbiornikowe zapadliska przedkarpackiego. Przegląd Geologiczny 2004, vol. 52, nr 7, s. 581-592.

[9] Oszczypko N.: Powstanie i rozwój polskiej części zapadliska przedkarpackiego. Przegląd Geologiczny 2006, vol. 54, nr 5, s. 396-402.

[10] Ringrose P.S.: Total-property modeling: Dispelling the net-togross myth. SPE Reservoir Evaluation \& Engineering 2008, vol. 11, nr 5, s. 866-873.

[11] Singh V., Yemez I., Sotomayor J.: Key factors affecting 3D reservoir interpretation and modeling outcomes: Industry perspectives. British Journal of Applied Science \& Technology 2013, vol. 3, nr 3, s. 376-405.

[12] Żelaźniewicz A., Aleksandrowski P., Buła Z., Karnkowski P.H., Konon A., Oszczypko N., Ślączka A., Żaba J., Żytko K.: Regionalizacja tektoniczna Polski. Komitet Nauk Geologicznych PAN 2011, s. 39-49.

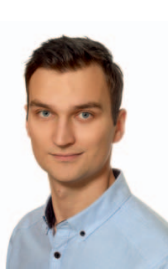

Mgr inż. Michał CIERZNIAK

Specjalista inżynieryjno-techniczny w Zakładzie

Podziemnego Magazynowania Gazu.

Instytut Nafty i Gazu - Państwowy Instytut Badawczy

ul. Lubicz 25 A

31-503 Kraków

E-mail: michal.cierzniak@inig.pl

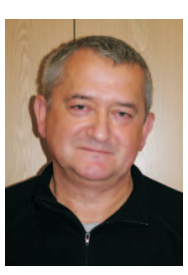

Mgr Mariusz MIZIOŁEK

Starszy specjalista badawczo-techniczny w Zakładzie Podziemnego Magazynowania Gazu. Instytut Nafty i Gazu - Państwowy Instytut Badawczy ul. Lubicz $25 \mathrm{~A}$

31-503 Kraków

E-mail: mariusz.miziolek@inig.pl 